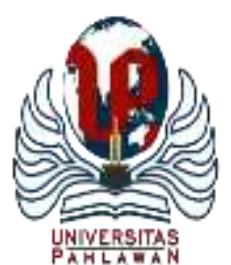

Edukatif : Jurnal Ilmu Pendidikan Volume 4 Nomor 1 Tahun 2022 Halm 1229 - 1243

EDUKATIF: JURNAL ILMU PENDIDIKAN

Research \& Learning in Education

https://edukatif.org/index.php/edukatif/index

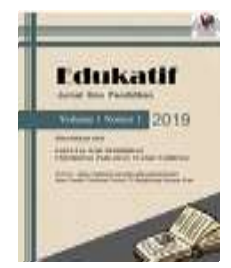

\title{
Pengembangan Buku Panduan Guru Materi Debit Berbasis Etnomatematika Menggunakan Tradisi Bercocok Tanam Padi di Kulon Progo
}

\author{
Syifa Aliffia $^{1 凶}$, Christiyanti Aprinastuti ${ }^{2}$, Maria Agustina Amelia ${ }^{3}$ \\ Universitas Sanata Dharma, Indonesia ${ }^{1,2,3}$ \\ E-mail : syifaaliffia@gmail.com ${ }^{1}, \underline{\text { christiyantia@usd.ac.id }}^{2}, \underline{\text { amelia@usd.ac.id }}^{3}$
}

\begin{abstract}
Abstrak
Penelitian ini dilatarbelakangi oleh kurangnya referensi buku panduan untuk guru mengajar materi debit berbasis etnomatematika menggunakan tradisi bercocok tanam padi yang menyenangkan. Penelitian ini bertujuan untuk mengembangkan dan mengetahui kualitas buku panduan guru materi debit berbasis etnomatematika menggunakan tradisi bercocok tanam padi di Kulon Progo. Penelitian ini merupakan jenis penelitian dan pengembangan R\&D. Subjek penelitian ini adalah guru kelas V SD. Objek penelitian ini adalah buku panduan guru materi debit berbasis etnomatematika menggunakan tradisi bercocok tanam padi di Kulon Progo. Pengumpulan data dalam penelitian ini menggunakan wawancara dan kuesioner. Hasil penelitian ini menunjukkan bahwa: (1) prosedur penelitian dan pengembangan buku panduan guru materi debit berbasis etnomatematika menggunakan tradisi bercocok tanam padi di Kulon Progo menggunakan langkah ADDIE, yaitu Analyze, Design, Development, Implementation, Evaluate; (2) kualitas buku panduan guru materi debit berbasis etnomatematika menggunakan tradisi bercocok tanam padi di Kulon Progo adalah sangat baik dengan skor 3,55 dari skala 4 dan memenuhi kriteria buku panduan yang berkualitas menurut Puskurbuk (2018:9-24) serta memenuhi kriteria penyusunan perencanaan pembelajaran menurut Sanjaya (dalam Ananda, 2019:20).

Kata Kunci: penelitian dan pengembangan, etnomatematika, tradisi bercocok tanam padi, debit.
\end{abstract}

\begin{abstract}
This research was motivated by the lack of reference guidebooks for teachers teaching ethnomathematicalbased flow rate materials using the fun tradition of rice farming. This study aims to develop and determine the quality of the teacher's manual for ethnomathematics-based flow rate materials using the tradition of rice cultivation in Kulon Progo. This research is a type of $R \& D$ research and development. The subject of this research is the fifth-grade elementary school teacher. The object of this research is a teacher's manual for ethnomathematics-based flow rate materials using the tradition of rice cultivation in Kulon Progo. Collecting data in this study used interviews and questionnaires. The results of this study indicate that: (1) the procedure for research and development of a teacher's manual for ethnomathematics-based flow rate materials using the tradition of rice cultivation in Kulon Progo uses the ADDIE step, namely Analyze, Design, Development, Implementation, Evaluate; (2) the quality of the teacher's guidebook for ethnomathematics-based flow rate materials using the tradition of rice cultivation in Kulon Progo is very good with a score of 3.55 out of a scale of 4 and meets the criteria for a quality guidebook according to Puskurbuk (2018:9-24) and meets the criteria for compiling learning planning according to Sanjaya (in Ananda, 2019:20).
\end{abstract}

Keywords: research and development, ethnomathematics, rice farming traditions, debit.

Copyright (c) 2022 Syifa Aliffia, Christiyanti Aprinastuti, Maria Agustina Amelia

$\triangle$ Corresponding author:

Email : syifaaliffia@gmail.com

DOI : https://doi.org/10.31004/edukatif.v4i1.2147

ISSN 2656-8063 (Media Cetak)

ISSN 2656-8071 (Media Online)

Edukatif : Jurnal Ilmu Pendidikan Vol 4 No 1 Tahun 2022 p-ISSN 2656-8063 e-ISSN 2656-8071 
1230 Pengembangan Buku Panduan Guru Materi Debit Berbasis Etnomatematika Menggunakan Tradisi Bercocok Tanam Padi di Kulon Progo - Syifa Aliffia, Christiyanti Aprinastuti, Maria Agustina Amelia DOI: https://doi.org/10.31004/edukatif.v4i1.2147

\section{PENDAHULUAN}

Matematika merupakan suatu ilmu logika mengenai bentuk, susunan, besaran, konsep-konsep yang saling berhubungan satu dengan yang lainnya dengan jumlah yang besar yang terbagi dalam tiga area atau bidang yaitu aljabar, analisis, dan geometri (Suherman, H.H, 2001). Pembelajaran matematika diajarkan pada berbagai jenjang pendidikan, mulai dari Taman Kanak-Kanak yang mengajarkan matematika secara informal sampai dengan tingkat Perguruan Tinggi. Matematika merupakan ilmu pasti yang tidak dapat dipisahkan dari kehidupan sehari-hari, baik dalam hal penerapan maupun penggunaannya. Hal tersebut seperti yang telah dikemukakan oleh Ubayanti (Suprayo et al., 2018) bahwa matematika sesungguhnya digunakan oleh setiap orang di dalam kehidupan sehari-hari. Namun, dalam hal penerapan maupun penggunaannya matematika dalam kehidupan sehari-hari banyak tidak disadari sehingga berjalan dengan alami.

Dalam dunia pendidikan, khususnya di Indonesia sering kali matematika tidak dipahami baik oleh peserta didik, sehingga seolah-olah matematika menjadi ilmu yang terpisah dari kehidupan sehari-hari. Oleh sebab itu, matematika dianggap menjadi momok dan mata pelajaran yang sulit untuk dipahami, membosankan, menyebalkan, rumit, dan tidak berguna. Pada kenyataannya, pendidikan di Indonesia telah menggunakan Kurikulum 2013. (Afifah, 2017) menjelaskan bahwa pembelajaran model tematik integratif yang digunakan dalam Kurikulum 2013 akan lebih menarik dan bermakna bagi anak karena menyajikan tematema pembelajaran yang lebih aktual dan kontekstual dengan kehidupan sehari-hari. Dengan demikian, pemilihan sumber belajar harus disesuaikan dengan karakteristik peserta didik yang berbeda-beda pada setiap daerah serta mengidentifikasi unsur budaya atau tradisi lokal, sehingga tercipta proses pembelajaran yang bermakna bagi peserta didik.

(Jamaris, 2014) menyatakan bahwa tujuan belajar matematika adalah mendorong siswa untuk menjadi pemecah masalah berdasarkan proses berpikir yang kritis, logis, dan rasional. National Council of Teachers of Mathematics (NCTM) (Jamaris, 2014) menyarankan bahwa dalam pembelajaran matematika, penekanan pada konsep matematika merupakan hal yang penting. Menurut Winebrener (Jamaris, 2014) penyajian konsepkonsep matematika perlu diurutkan dari proses konkret ke proses semi konkret, dan selanjutnya ke proses abstrak. Penyajian konsep matematika yang urut mulai dari proses konkret, semi konkret, dan abstrak akan memudahkan peserta didik dalam memahami atau menanamkan konsep matematika. Sejauh ini, penyebab matematika dianggap sebagai mata pelajaran yang sulit dan menyebalkan dikarenakan dalam penyajiannya secara langsung diberikan secara abstrak tanpa melalui proses konkret dan semi konkret.

Freudental (Susanto, 2013) menjelaskan bahwa matematika merupakan aktivitas insani (human activities) dan harus dikaitkan dengan realitas. Indonesia merupakan negara yang kaya akan beragam suku bangsa. Menurut Badan Pusat Statistik, salah satu suku bangsa terbesar di Indonesia adalah suku Jawa yang mencapai 40,05\% dari jumlah penduduk di Indonesia. Kehidupan masyarakat Jawa sangat kental dengan budaya-budaya atau tradisi-tradisi. Budaya (kebudayaan) adalah keseluruhan gagasan dan karya manusia yang harus dibiasakannya dengan belajar, beserta keseluruhan dari hasil budi dan karyanya itu (Koentjaraningrat, dalam Suwarsono, 2015). Sedangkan menurut Kamus Besar Bahasa Indonesia, tradisi merupakan adat kebiasaan turun-temurun (dari nenek moyang) yang masih dijalankan dalam kehidupan masyarakat.

Proses pembelajaran matematika yang disajikan dengan konkret sesuai dengan realitas dapat diberikan melalui proses pembelajaran yang terintegrasi dengan budaya/tradisi yang biasa disebut sebagai Etnomatematika. Zhang dan Zhang (Irsyad et al., 2020) menyatakan jika etnomatematika bisa dikatakan sebagai proses untuk mencari hubungan antara matematika dan budaya. Hubungan yang dimaksud dalam penjelasan tersebut yaitu bagaimana matematika tersebut diproduksi, ditransfer, disebarkan, dan dikhususkan dalam beragam sistem budaya.

Budaya atau tradisi yang dimiliki oleh masyarakat Indonesia semakin tidak terimplementasikan di tengah kehidupan yang semakin instan dan konsumtif. Pada peserta didik Sekolah Dasar pengetahuan 
1231 Pengembangan Buku Panduan Guru Materi Debit Berbasis Etnomatematika Menggunakan Tradisi Bercocok Tanam Padi di Kulon Progo - Syifa Aliffia, Christiyanti Aprinastuti, Maria Agustina Amelia DOI: https://doi.org/10.31004/edukatif.v4i1.2147

mengenai budaya atau tradisi tersebut sudah jarang diketahui atau dikenal. Hal tersebut dikarenakan peserta didik Sekolah Dasar yang sudah lekat dengan gadget yang menyebabkan hilangnya sikap melestarikan budaya atau tradisi yang dimiliki oleh setiap daerah. Pendidikan dan kebudayaan menurut Ki Hajar Dewantara (Oktavianti et al., 2017) merupakan sistem among, yang artinya pendidikan sebenarnya tidak hanya mencetak generasi yang memiliki pengetahuan dan kecerdasan, melainkan pendidikan juga perlu mengembangkan budi pekerti pada diri peserta didik sesuai dengan kebudayaan bangsa. Penanaman budaya atau tradisi pada peserta didik di dunia pendidikan penting untuk menanamkan identitas dan jati diri bangsa yang mulai tergerus oleh dampak dari arus globalisasi.

Peneliti telah melakukan analisis kebutuhan, dengan cara melakukan wawancara kepada lima guru kelas V SD di daerah Yogyakarta, Temanggung, dan Jakarta pada bulan Februari 2020 dan September 2020. Peneliti memperoleh data bahwa: (1) materi matematika yang masih menjadi kendala bagi peserta didik kelas V SD adalah materi debit, peserta didik belum mampu menanamkan konsep debit dengan baik, dalam proses menghitung menggunakan rumus debit peserta didik telah mampu melakukannya, namun dalam merubah satuan volume atau satuan waktu, peserta didik masih mengalami kesulitan; (2) pemahaman peserta didik mengenai budaya atau tradisi lokal terbatas, hal tersebut dikarenakan saat ini peserta didik telah lekat dengan gadget dan pengaruh perkembangan teknologi serta globalisasi yang menyebabkan pelestarian budaya atau tradisi pada usia anak-anak dianggap sebagai hal yang kuno atau tidak mengikuti perkembangan zaman; (3) 3 dari 5 guru pernah mengintegrasikan pembelajaran matematika dengan budaya atau tradisi lokal, seperti dengan permainan congklak, kegiatan pembuatan gula jawa, dan jadah tempe; (4) guru mengalami keterbatasan ketika menciptakan pembelajaran yang terintegrasi dengan budaya atau tradisi dikarenakan minimnya buku referensi yang dimiliki; (5) guru membutuhkan sebuah referensi berupa buku panduan guru yang mampu mengintegrasikan pembelajaran matematika dengan budaya atau tradisi yang ada di lingkungan kehidupan sehari-hari, sehingga tercipta pembelajaran yang inovatif dan menyenangkan, serta tercipta keseimbangan antara pendidikan dan kebudayaan.

Berdasarkan hasil analisis kebutuhan lima guru kelas V SD di daerah Yogyakarta, Temanggung, dan Jakarta, peneliti memperoleh data bahwa guru membutuhkan sebuah referensi berupa buku panduan guru materi debit berbasis etnomatematika menggunakan tradisi bercocok tanam padi di Kulon Progo yang bisa membantu guru dalam menciptakan atau menerapkan proses pembelajaran matematika yang terintegrasi dengan budaya atau tradisi. Buku panduan untuk pendidik merupakan buku yang ditujukkan untuk guru serta didalamnya terdapat sebuah prinsip, prosedur, deskripsi tentang materi pokok yang akan dibahas, serta model pembelajaran yang dapat digunakan dalam menyampaikan materi pembelajaran oleh pendidik kepada peserta didik (Sitepu, 2012).

Oleh sebab itu, berdasarkan uraian di atas peneliti terinspirasi untuk melaksanakan penelitian dan pengembangan (Research and Development) berupa buku panduan guru berbasis etnomatematika menggunakan tradisi bercocok tanam padi di Kulon Progo. Materi yang dipaparkan dalam buku panduan guru yaitu materi debit untuk kelas V SD. Buku panduan guru memungkinkan guru untuk mampu mengimplementasikan tradisi bercocok tanam padi di Kulon Progo yang dikaitkan dengan pembelajaran matematika materi debit. Melalui buku panduan guru juga memungkinkan guru untuk menanamkan sikap melestarikan budaya atau tradisi pada diri peserta didik, terkhusus pada tradisi bercocok tanam padi. Menurut peneliti pribadi, tradisi bercocok tanam padi sangat akrab di mata peserta didik Sekolah Dasar. Hal tersebut dikarenakan sektor pertanian terkhusus di daerah Jawa masih sangat banyak yang terbukti dengan banyaknya hamparan area persawahan yang luas, seperti di daerah Kulon Progo yang mencapai 9.306 Ha (data Badan Pusat Statistik, 2017). Selain itu berdasarkan wawancara yang dilakukan dengan beberapa petani di dusun Degan I, Kulon Progo, masyarakat masih mempertahankan pekerjaan sebagai petani untuk mata pencaharian dalam memenuhi kebutuhan hidup sehari-hari. Hal tersebut terbukti dengan data Badan Pusat Statistik pada tahun 2017 yang menyatakan bahwa 96,59 \% penduduk di Kulon Progo bermata pencaharian sebagai petani. 
1232 Pengembangan Buku Panduan Guru Materi Debit Berbasis Etnomatematika Menggunakan Tradisi Bercocok Tanam Padi di Kulon Progo - Syifa Aliffia, Christiyanti Aprinastuti, Maria Agustina Amelia DOI: https://doi.org/10.31004/edukatif.v4i1.2147

Petani Kulon Progo juga masih melestarikan tradisi-tradisi bercocok tanam padi secara tradisional yang sudah mulai tergerus oleh arus globalisasi. Penelitian terdahulu yang dilakukan oleh Try Suprayo, Nuryusri, dan Muchamad Subali Noto (2018) dengan judul "Studi Etnomatematika Masyarakat Petani Kabupaten Cirebon" memperoleh kesimpulan bahwa kegiatan masyarakat petani Desa Suranenggala Kidul dan Gegesik Cirebon memuat unsur-unsur matematika berupa satuan tertentu seperti satuan panjang, satuan luas, dan satuan volume, serta matematika dasar yang dapat digunakan sebagai media atau pendekatan dalam pembelajaran matematika di sekolah. Oleh sebab itu, peneliti meyakini bahwa tradisi bercocok tanam padi mampu diintegrasikan dalam pembelajaran matematika terkhusus pada materi debit untuk kelas V SD. Namun, berdasarkan banyak penelitian terdahulu mengenai etnomatematika seperti penelitian terdahulu yang dilakukan oleh Nurul Haque (Model et al., 2015) mengenai Pengaruh Model Pembelajaran Etnomatematika Sunda untuk Meningkatkan Kemampuan Berpikir Kritis Siswa Sekolah Dasar (Didactical Design Research dan Studi Eksperimen di Kelas V SDN Drangong 1) dan penelitian Sarwoedi, Desi Okta Marinka, Peni Febriani, dan I Nyoman Wirne (Sarwoedi et al., 2018) mengenai Efektifitas Etnomatematika dalam Meningkatkan Kemampuan Pemahaman Matematika Siswa, hanya penggunaan etnomatematika saja yang dikembangkan dalam pembelajaran matematika, belum ada penelitian yang mengembangkan buku panduan guru dalam pembelajaran matematika materi debit berbasis etnomatematika menggunakan tradisi bercocok tanam padi untuk kelas V SD. Sehingga, pembaruan penelitian yang dikembangkan oleh peneliti yaitu pengembangan berupa buku panduan guru dalam pembelajaran matematika materi debit berbasis etnomatematika menggunakan tradisi bercocok tanam padi untuk kelas V SD, yang ditujukan kepada guru kelas V Sekolah Dasar. Dalam penyusunan buku panduan guru berbasis etnomatematika ini, peneliti menggunakan kriteria buku panduan yang berkualitas menurut (Pusat Perbukuan, 2018) dan kriteria penyusunan perencanaan pembelajaran menurut Sanjaya (Ananda, 2019).

Penelitian ini penting untuk dilaksanakan saat ini dikarenakan seiring dengan perkembangan ilmu pengetahuan dan teknologi yang terus berkembang pesat menyebabkan munculnya era globalisasi yang menawarkan gaya hidup yang semakin instan dan konsumtif. Hal tersebut yang menyebabkan budaya atau tradisi yang dimiliki oleh masyarakat Indonesia semakin tidak terimplementasikan dalam kehidupan seharihari. (Ramadan, 2018) menjelaskan bahwa masyarakat menggunakan cara-cara tersendiri untuk mengelola alam dan lingkungannya dengan nilai, kepercayaan, dan sistem religi yang dianutnya serta pada intinya kegiatan tersebut untuk melindunggi dan melestarikan alam dan lingkungannya. Namun, saat ini teknologi dan masalah sosial yang bergitu berkembang dengan pesat menyebabkan budaya atau tradisi semakin tersingkirkan terlebih pada peserta didik Sekolah Dasar yang sudah jarang mengetahui atau mengenal budaya atau tradisi yang ada di masyarakat. Hal tersebut dikarenakan peserta didik Sekolah Dasar yang sudah lekat dengan gadget yang menyebabkan hilangnya sikap melestarikan budaya atau tradisi yang dimiliki setiap daerah. Padahal, pada kenyataannya penanaman budaya atau tradisi pada peserta didik di dunia pendidikan penting untuk dilakukan untuk menanamkan identitas dan jati diri bangsa yang mulai tergerus oleh dampak dari arus globalisasi. (Ramadan, 2018) menyatakan bahwa karakter-karakter budaya bangsa yang sangat baik dan perlu diajarkan sehingga siswa tidak lupa di mana mereka tinggal dan hidup serta di mana mereka bermasyarakat, sehingga melalui penanaman kearifan di Sekolah Dasar sangat membantu siswa dalam membentuk karakter budaya bangsa.

Selain itu, penelitian ini juga penting dilaksanakan dikarenakan National Council of Teachers of Mathematics (NCTM) (Jamaris, 2014) menyarankan bahwa dalam pembelajaran matematika, penekanan pada konsep matematika merupakan hal penting. Menurut Winebrener (Jamaris, 2014) penyajian konsep-konsep matematika perlu diurutkan dari proses konkret ke proses semi konkret, dan selanjutnya ke proses abstrak. Penyajian konsep matematika yang urut mulai dari proses konkret, semi konkret, dan abstrak akan memudahkan peserta didik dalam memahami atau menanamkan konsep matematika. Sejauh ini, penyebab matematika dianggap sebagai mata pelajaran yang sulit dan menyebalkan dikarenakan dalam penyajiannya 
1233 Pengembangan Buku Panduan Guru Materi Debit Berbasis Etnomatematika Menggunakan Tradisi Bercocok Tanam Padi di Kulon Progo - Syifa Aliffia, Christiyanti Aprinastuti, Maria Agustina Amelia DOI: https://doi.org/10.31004/edukatif.v4i1.2147

secara langsung diberikan secara abstrak tanpa melalui proses konkret dan semi konkret. Mercer (Jamaris, 2014) menjelaskan bahwa perkembangan kemampuan yang harus dimiliki oleh peserta didik Sekolah Dasar untuk melakukan kegiatan matematika yang lebih tinggi secara berurutan mencakup, berikut ini: (1) perubahan berdasarkan hasil penjumlahan, yang berarti tanpa menghiraukan tempatnya, bilangan yang sama apabila digabungkan atau dijumlahkan akan menghasilkan jumlah yang konstan; (2) perubahan berdasarkan hasil perkalian, yang berarti tanpa menghiraukan tempat bilangan yang sama apabila dikalikan akan menghasilkan hasil yang konstan; (3) perubahan berdasarkan asosiasi penjumlahan dan perkalian, yang berarti hasil penggabungan penjumlahan dan perkalian bilangan yang sama tanpa menghiraukan tempat bilangan tersebut akan menghasilkan hasil yang tetap; dan (4) distribusi perkalian atas penjumlahan. Pernyataan Mercer tersebut, sesuai dengan hasil wawancara yang dilakukan dengan lima guru kelas V Sekolah Dasar yang menyatakan bahwa kemampuan yang seharusnya telah dimiliki oleh peserta didik kelas V SD yaitu lancar dalam materi operasi hitung. Operasi hitung merupakan materi pokok yang seharusnya telah dikuasai baik oleh peserta didik, namun dalam fakta di lapangan banyak peserta didik kelas atas yang belum menguasai dengan baik materi operasi hitung sehingga menyebabkan peserta didik belum menguasai dengan baik materi matematika lain seperti materi debit. Apabila dasar operasi hitung telah dikuasai dengan baik, maka materi matematika lainnya akan mudah untuk dikuasai.

Rumusan masalah dalam penelitian ini adalah: (1) Bagaimana mengembangkan buku panduan guru materi debit berbasis etnomatematika menggunakan tradisi bercocok tanam padi di Kulon Progo?; (2) Bagaimana kualitas buku panduan guru materi debit berbasis etnomatematika menggunakan tradisi bercocok tanam padi di Kulon Progo?

Berdasarkan rumusan masalah tersebut maka tujuan penelitian ini adalah: (1) Mengembangkan buku panduan guru materi debit berbasis etnomatematika menggunakan tradisi bercocok tanam padi di Kulon Progo; (2) Mengetahui kualitas buku panduan guru materi debit berbasis etnomatematika menggunakan tradisi bercocok tanam padi di Kulon Progo.

\section{METODE PENELITIAN}

Metode dalam penelitian ini adalah penelitian dan pengembangan (Research \& Development) dengan menggunakan prosedur penelitian dan pengembangan model ADDIE (Analyze, Design, Development, Implementation, and Evaluation). Penelitian ini dilaksanakan pada bulan Februari 2020 - Maret 2021. Penelitian dilaksanakan di lima sekolah yaitu: (1) SD Joannes Bosco yang terletak di Jl. Melati Wetan No. 53, Baciro, Kecamatan Gondokusuman, Kota Yogyakarta, Daerah Istimewa Yogyakarta 55225; (2) SD Kanisius Sengkan yang terletak di Jl. Kaliurang KM 7, Joho, Condongcatur, Kecamatan Depok, Kabupaten Sleman, Daerah Istimewa Yogyakarta 55283; (3) SD N Triwidadi yang terletak di Pajangan, Triwidadi, Kecamatan Pajangan, Kabupaten Bantul, Daerah Istimewa Yogyakarta 55751; (4) SD N Jombor yang terletak di Kuncen, Jombor, Jumo, Kabupaten Temanggung, Jawa Tengah 56256; dan (5) SD N Pekojan 01 Pagi yang terletak di J1. Pekojan No. 161-163, Tambora, RT 05 RW 06, Pekojan, Kecamatan Tambora, Kota Jakarta Barat, Daerah Khusus Ibukota Jakarta 11240. Subjek penelitian ini adalah guru kelas V SD.

Teknik pengumpulan data yang digunakan yaitu wawancara dan kuesioner. Instrumen dalam penelitian ini yaitu pedoman wawancara dan kuesioner validasi produk. Teknik analisis data yang digunakan dalam penelitian yaitu kuantitatif dan kualitatif.

Instrumen pedoman wawancara dalam penelitian ini terdiri dari 22 item pertanyaan, yang dikembangkan dari 12 topik pertanyaan, dan terdiri dari 3 kisi-kisi. Kisi-kisi yang digunakan oleh peneliti berdasarkan tahapan analisis model ADDIE menurut (Tegeh, I.M, Jampel, I.N, Pudjawan, 2014) meliputi analisis materi, analisis karakteristik peserta didik, dan analisis kompetensi. Berikut tabel kisi-kisi wawancara kepada guru kelas V SD. 
1234 Pengembangan Buku Panduan Guru Materi Debit Berbasis Etnomatematika Menggunakan Tradisi Bercocok Tanam Padi di Kulon Progo - Syifa Aliffia, Christiyanti Aprinastuti, Maria Agustina Amelia DOI: https://doi.org/10.31004/edukatif.v4i1.2147

\section{Tabel 1}

Kisi-kisi Wawancara kepada Guru Kelas V SD

Topik Pertanyaan

\author{
No. Item
}

Kesulitan yang dialami guru dalam pembelajaran matematika.

Usaha yang dilakukan untuk mengatasi kesulitan yang dialami guru dalam pembelajaran

matematika.

Referensi mengajar yang digunakan guru dalam membantu proses pembelajaran 10

matematika.

Proses pembelajaran matematika yang terintegrasi dengan budaya atau tradisi.

Pendapat guru jika materi pembelajaran matematika diajarkan dengan budaya atau tradisi 12

bercocok tanam padi.

Hasil yang diharapkan

Karakteristik peserta didik kelas V SD yang akan mengikuti proses pembelajaran.

14

15,16

Kesulitan yang dialami peserta didik dalam pembelajaran matematika.

17,18

Usaha yang dilakukan guru untuk mengatasi kesulitan yang dialami peserta didik dalam

pembelajaran matematika.

Partisipasi peserta didik dalam mengikuti pembelajaran matematika tatap muka/jarak jauh.

Pengetahuan peserta didik mengenai budaya atau tradisi lokal.

19,20

Kompetensi yang dimiliki peserta didik.

22

Instrumen kuesioner validasi produk dalam penelitian ini terdiri dari 28 item pernyataan, yang dikembangkan dari 7 indikator kriteria buku panduan berkualitas menurut (Pusat Perbukuan, 2018) dan 6 indikator kriteria penyusunan perencanaan pembelajaran menurut Sanjaya (Ananda, 2019). Instrumen kuesioner validasi produk ini menggunakan skala Likert 4, yaitu: Sangat Baik (4); Baik (3); Kurang Baik (2); dan Sangat Kurang Baik (1). Instrumen ini digunakan untuk memperoleh data validasi produk. Berikut tabel kisi-kisi kuesioner validasi produk.

\section{Tabel 2}

Kisi-kisi Kuesioner Validasi Produk

Indikator No. Item

\begin{tabular}{|c|c|c|}
\hline $\begin{array}{l}\text { Kriteria Buku } \\
\text { Panduan }\end{array}$ & $\begin{array}{l}\text { 1. Judul buku menggambarkan isi buku yang ditulis dalam bahasa } \\
\text { Indonesia yang baik dan benar. }\end{array}$ & $1,2,3$ \\
\hline Berkualitas & 2. Ilustrasi cover buku menggambarkan isi buku. & 4 \\
\hline \multirow{6}{*}{$\begin{array}{l}\text { (Puskurbuk, } \\
\text { 2018) }\end{array}$} & 3. Halaman prakata yang ditulis oleh penulis buku atau kata & 5 \\
\hline & pengantar yang ditulis oleh orang lain tentang materi buku. & \\
\hline & 4. Halaman daftar isi, daftar tabel atau daftar gambar. & $\begin{array}{lllll}6 & & & & \\
7 & 8 & 0 & 10 & 0\end{array}$ \\
\hline & $\begin{array}{l}\text { 5. Memberikan panduan tentang metode, media, dan penilaian } \\
\text { pembelajaran guna meningkatkan kapasitas pedagogik, sosial, dan } \\
\text { profesionalitas pendidik. }\end{array}$ & $\begin{array}{l}7,8,9,10 \\
11,12,13 \\
14,15\end{array}$ \\
\hline & $\begin{array}{l}\text { 6. Memiliki muatan isi yang dapat dipertanggungjawabkan, dengan } \\
\text { mencantumkan sumber rujukan pada daftar referensi di halaman } \\
\text { akhir buku. }\end{array}$ & 16 \\
\hline & $\begin{array}{l}\text { 7. Memiliki tata bahasa dan gaya penyajian yang baik agar mudah } \\
\text { dipahami. Buku-buku hasil alih bahasa dari bahasa asing ke bahasa } \\
\text { Indonesia harus memiliki kualitas terjemahan yang baik. }\end{array}$ & 17,18 \\
\hline Kriteria & 1. Signifikansi & 19,20 \\
\hline Penyusunan & 2. Relevan & $21,22,23$ \\
\hline Perencanaan & 3. Kepastian & 24 \\
\hline Pembelajaran & 4. Adaptabilitas & 25 \\
\hline (Ananda, & 5. Kesederhanaan & 26 \\
\hline 2019) & 6. Prediktif & 27,28 \\
\hline
\end{tabular}


Dalam perhitungan data validasi produk buku panduan guru materi debit berbasis etnomatematika menggunakan tradisi bercocok tanam padi di Kulon Progo ini, peneliti menggunakan instrumen skala empat. Berikut ini merupakan skala empat menurut (Mardapi, 2008) yang telah dikonversikan.

Tabel 3

Skor Skala Empat Menurut (Mardapi, 2008)

\begin{tabular}{cc}
\hline Interval & Kategori \\
\hline $\mathrm{X} \geq \overline{\overline{\mathrm{X}}}+1 . \mathrm{SBx}$ & Sangat Positif/Sangat Tinggi \\
$\overline{\mathrm{X}}+1 . \mathrm{SBX}>\mathrm{X} \geq \overline{\mathrm{X}}$ & Tinggi/Positif \\
$\overline{\overline{\mathrm{X}}}>\mathrm{X} \geq \overline{\overline{\mathrm{X}}}-1 . \mathrm{SBx}$ & Negatif/Rendah \\
$\mathrm{X}<\overline{\overline{\mathrm{X}}}-1 . \mathrm{SBx}$ & Sangat Negatif/Rendah \\
\hline
\end{tabular}

Data hasil validasi kemudian dihitung nilai reratanya, dan dikonversikan dari data kuantitatif ke data kualitatif skala empat menurut (Mardapi, 2008). Berikut hasil perhitungan konversi data kuantitatif ke data kualitatif skala empat.

\section{Tabel 4}

\begin{tabular}{cc}
\multicolumn{2}{c}{ Kriteria Skor Skala Empat } \\
\hline Interval & Kategori \\
\hline$X \geq 3$ & Sangat Baik \\
$3>X \geq 2,5$ & Baik \\
$2,5>X \geq 2$ & Kurang Baik \\
$X<2$ & Sangat Kurang Baik \\
\hline
\end{tabular}

Teknik analisis data dalam penelitian ini terdiri dari dua, yaitu (1) analisis data kualitatif diperoleh dari data analisis kebutuhan dan data hasil validasi produk; (2) analisis data kuantitatif diperoleh dari data hasil validasi produk oleh satu ahli matematika, satu ahli budaya/tradisi, satu ahli pertanian, dan satu guru kelas $\mathrm{V}$ SD.

\section{HASIL DAN PEMBAHASAN PENELITIAN}

Prosedur pengembangan buku panduan guru materi debit berbasis etnomatematika menggunakan tradisi bercocok tanam padi di Kulon Progo, menggunakan langkah-langkah dari model ADDIE. Berikut ini merupakan hasil dan pembahasan penelitian pengembangan produk buku panduan guru menggunakan lima langkah ADDIE (Tegeh, I.M, Jampel, I.N, Pudjawan, 2014).

\section{Analyze (Analisis)}

Langkah pertama yang dilakukan oleh peneliti yaitu melaksanakan analisis kebutuhan untuk memperoleh data yang dilaksanakan dengan cara wawancara kepada lima guru kelas V SD di daerah Yogyakarta, Temanggung, dan Jakarta. Hasil wawancara menunjukkan bahwa: (1) dalam proses pembelajaran matematika, guru jarang menggunakan media atau alat peraga pembelajaran, guru hanya memanfaatkan benda-benda di sekitar untuk membantunya dalam menjelaskan materi dan menggunakan media powerpoint untuk menampilkan video pembelajaran serta latihan soal; (2) guru mengeluh bahwa terdapat sebagian peserta didik kelas V SD yang belum lancar dalam materi operasi hitung, sehingga menyebabkan terkendalanya dalam memahami materi yang lainnya; (3) materi matematika yang masih menjadi kendala bagi peserta didik kelas V SD adalah materi debit, peserta didik belum mampu menanamkan konsep debit dengan baik, dalam proses menghitung menggunakan rumus debit peserta didik telah mampu melakukannya, namun dalam merubah satuan volume atau satuan waktu, peserta didik masih mengalami kesulitan; (4) variasi pembelajaran yang digunakan guru yaitu menggunakan diskusi kerja kelompok, teman sejawat, dan berbagai permainan, hal tersebut dikarenakan menurut guru bahasa teman sejawat lebih mudah dipahami dibandingkan bahasa guru dan permainan akan menarik bagi peserta didik sehingga ketika peserta didik merasa senang, materi yang disampaikan akan lebih mudah dipahami; (5) untuk menciptakan media pembelajaran serta pembelajaran yang 
inovatif dan menyenangkan, guru mengalami kesulitan karena terbatasnya buku referensi yang dimiliki, referensi yang biasa digunakan yaitu buku guru, buku siswa, sumber-sumber internet, dan youtube; (6) guru juga menyampaikan bahwa tidak jarang dalam proses pembelajaran tidak menggunakan media atau model pembelajaran yang inovatif, guru cenderung memberikan latihan soal-soal secara terus menerus sehingga peserta didik merasa bosan, sulit memahami materi, dan mudah menyerah ketika menghadapi soal yang rumit karena kurangnya motivasi dan variasi proses pembelajaran yang digunakan; (7) sebagian guru belum pernah mengintegrasikan pembelajaran matematika dengan budaya atau tradisi lokal masyarakat, tetapi sebagian guru pernah mengintegrasikan pembelajaran matematika dengan permainan congklak, kegiatan pembuatan gula jawa, dan jadah tempe; (8) pemahaman peserta didik mengenai budaya atau tradisi lokal terbatas, hal tersebut dikarenakan saat ini peserta didik telah lekat dengan gadget dan pengaruh perkembangan teknologi serta globalisasi yang menyebabkan pelestarian budaya atau tradisi pada usia anak-anak dianggap sebagai hal yang kuno atau tidak mengikuti perkembangan zaman; (9) guru mengalami keterbatasan ketika menciptakan pembelajaran yang terintegrasi dengan budaya atau tradisi dikarenakan minimnya buku referensi yang dimiliki; (10) guru membutuhkan sebuah referensi berupa buku panduan guru yang mampu mengintegrasikan pembelajaran matematika dengan budaya atau tradisi yang ada di lingkungan kehidupan sehari-hari, sehingga tercipta pembelajaran yang inovatif dan menyenangkan, serta tercipta keseimbangan antara pendidikan dan kebudayaan.

\section{Design (Perancangan)}

Langkah kedua yang dilakukan yaitu mengidentifikasi unsur-unsur yang perlu dilampirkan dalam buku panduan guru, dalam langkah ini peneliti melakukan identifikasi berdasarkan hasil wawancara yang dilakukan kepada lima guru kelas V SD disalah satu sekolah di daerah Yogyakarta, Temanggung, dan Jakarta. Kemudian peneliti mulai menentukan budaya atau tradisi yang kontekstual dengan kehidupan peserta didik dan memudahkan guru untuk mengintegrasikannya dalam proses pembelajaran matematika materi debit. Peneliti memilih tradisi bercocok tanam padi di Kulon Progo untuk diintegrasikan ke dalam proses pembelajaran matematika. Peneliti juga mencari sumber-sumber terkait materi debit kelas V SD dan tradisi bercocok tanam padi di Kulon Progo supaya sesuai dengan Kompetensi Dasar dan karakteristik peserta didik. Kemudian peneliti mulai merancang desain buku dan tata letak tulisan dalam buku panduan guru.

\section{Development (Pengembangan)}

Langkah ketiga yang dilakukan yaitu peneliti mencari dan mengumpulkan sumber-sumber yang dapat mendukung pengembangan buku panduan guru etnomatematika tradisi bercocok tanam padi di Kulon Progo materi debit untuk kelas $5 \mathrm{SD}$. Peneliti juga melakukan pengambilan gambar mengenai tradisi bercocok tanam padi di dusun Degan I, Kulon Progo, untuk dicantumkan dalam buku panduan guru. Selain itu, peneliti mulai menyusun isi buku panduan guru yang telah dirancang pada tahap sebelumnya. Peneliti juga melakukan pengaturan layout dan kesesuaian warna. Dalam pengembangan buku panduan guru, peneliti menggunakan kriteria buku panduan yang berkualitas menurut (Pusat Perbukuan, 2018) serta kriteria penyusunan perencanaan pembelajaran menurut Sanjaya (Ananda, 2019).

\section{Implementation (Implementasi)}

Pada tahap implementasi, peneliti tidak melaksanakannya dikarenakan terhambat oleh adanya pandemi Covid-19 yang melanda dunia termasuk Indonesia. Hal tersebut membuat pemerintah Indonesia secara resmi mengeluarkan aturan atau perintah mengenai proses pembelajaran pada seluruh jenjang pendidikan di Indonesia dilaksanakan secara jarak jauh atau daring. Lima guru kelas V SD disalah satu sekolah di daerah Yogyakarta, Temanggung, dan Jakarta, menyampaikan bahwa merasa tidak sanggup untuk melakukan uji coba produk di masa pandemi. Hal tersebut dikarenakan, di masa pandemi ini banyak tugas guru yang perlu diselesaikan selain mengajar peserta didik. Guru juga tidak berani membebani peserta didik dengan tugas tambahan, dikarenakan banyak orangtua yang mengeluh jika peserta didik diberikan tugas tambahan. Hal lain 

Bercocok Tanam Padi di Kulon Progo - Syifa Aliffia, Christiyanti Aprinastuti, Maria Agustina Amelia DOI: https://doi.org/10.31004/edukatif.v4i1.2147

yang juga menjadi pertimbangan guru tidak mengizinkan uji coba produk yaitu kemampuan dan hasil yang didapatkan tidak dapat diukur dengan baik, dikarenakan tidak dapat dipungkiri bahwa di masa pandemi proses pembelajaran yang dilaksanakan secara jarak jauh menyebabkan dalam mengerjakan tugas sekolah tidak murni hasil pekerjaan peserta didik namun terdapat campur tangan orangtua. Sehingga untuk mengetahui kualitas produk yang dihasilkan, peneliti hanya melakukan validasi produk kepada satu ahli matematika, satu ahli budaya atau tradisi, satu ahli pertanian, dan satu guru kelas V SD.

\section{Evaluation (Evaluasi)}

Langkah terakhir yang dilakukan peneliti yaitu melakukan evaluasi berdasarkan komentar, saran atau masukan dari validator untuk melakukan revisi atau perbaikan. Evaluasi yang dilakukan peneliti meliputi evaluasi formatif yang berupa hasil validasi produk oleh ahli matematika, ahli budaya atau tradisi, ahli pertanian, dan guru kelas V SD, serta evaluasi sumatif berdasarkan komentar, saran atau masukan dari data validasi produk oleh ahli matematika, ahli budaya atau tradisi, ahli pertanian, dan guru kelas V SD untuk memperbaiki kualitas produk dan evaluasi kualitas produk. Dalam langkah ini, peneliti memperbaiki produk akhir berdasarkan evaluasi selama penelitian.

Kualitas produk buku panduan guru etnomatematika tradisi bercocok tanam padi di Kulon Progo materi debit untuk kelas 5 SD, yang telah dibuat oleh peneliti mempunyai kualitas "Sangat Baik" dengan rerata skor validasi sebesar 3,55 dari skala empat. Buku panduan guru juga telah memenuhi kriteria buku panduan berkualitas menurut (Pusat Perbukuan, 2018), yaitu:

1. Buku panduan guru yang telah dirancang oleh peneliti telah memiliki judul buku yang menggambarkan keseluruhan isi buku yang ditulis dengan menggunakan bahasa Indonesia baku sesuai dengan Kamus Besar Bahasa Indonesia (KBBI). Hal tersebut sudah sesuai dengan kriteria buku panduan berkualitas menurut (Pusat Perbukuan, 2018) mengenai cover buku yaitu judul buku menggambarkan isi buku yang ditulis dalam bahasa Indonesia yang baik dan benar.

2. Buku panduan guru memiliki sampul yang menggunakan foto-foto konkret mengenai tradisi bercocok tanam padi yang diambil secara langsung oleh peneliti di dusun Degan I, Kulon Progo dan gambar ilustrasi mengenai rumus matematika materi debit yang berguna untuk menggambarkan keseluruhan isi buku panduan guru yang telah peneliti susun. Hal ini sudah sesuai dengan kriteria buku panduan berkualitas menurut (Pusat Perbukuan, 2018) mengenai cover buku yaitu ilustrasi cover buku menggambarkan isi buku. 

Bercocok Tanam Padi di Kulon Progo - Syifa Aliffia, Christiyanti Aprinastuti, Maria Agustina Amelia DOI: https://doi.org/10.31004/edukatif.v4i1.2147

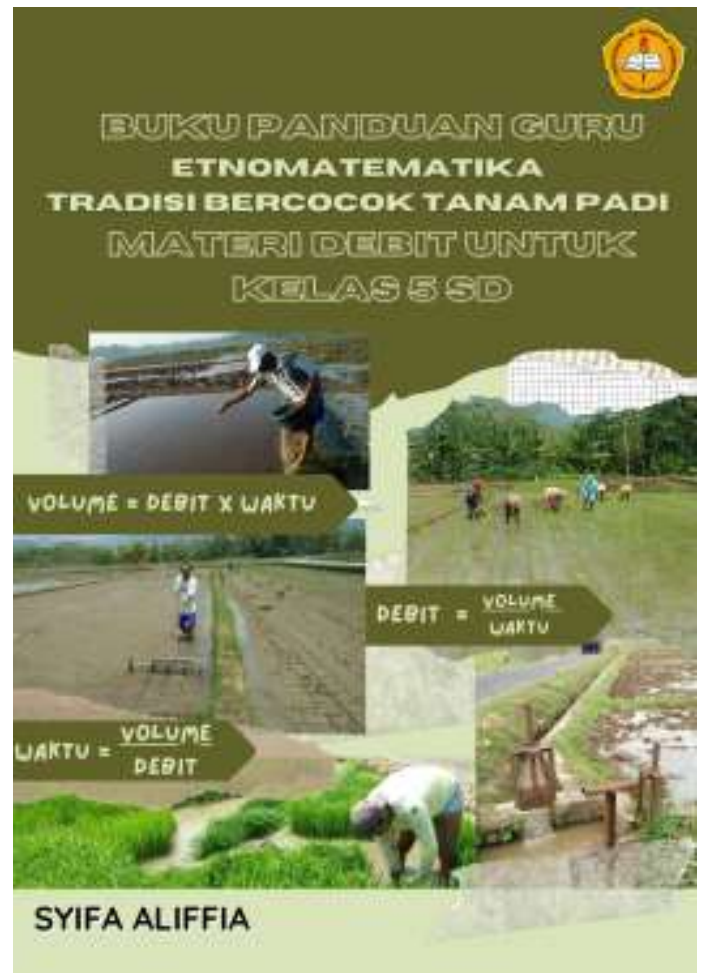

Gambar 1. Cover Buku Panduan

3. Pada bagian awal buku panduan guru yang telah peneliti susun terdapat kata pengantar yang ditulis oleh peneliti. Hal tersebut telah sesuai dengan kriteria buku panduan berkualitas menurut (Pusat Perbukuan, 2018) mengenai bagian awal buku/prelim yaitu halaman prakata yang ditulis oleh penulis buku atau kata pengantar yang ditulis oleh orang lain tentang materi buku.

4. Buku panduan guru dilengkapi dengan daftar isi. Daftar isi yang disusun telah sesuai dengan halaman isi, sehingga buku panduan guru sesuai dengan kriteria buku panduan berkualitas menurut (Pusat Perbukuan, 2018) mengenai bagian awal buku/prelim yaitu halaman daftar isi, daftar tabel atau daftar gambar.

5. Buku panduan guru berisikan penjelasan teori etnomatematika, teori tradisi bercocok tanam padi, teori debit, dan teori model pembelajaran Problem Based Learning (PBL) yang berguna untuk menambah pemahaman pembaca atau pengguna buku panduan guru. Selain itu, buku panduan juga berisi RPP yang dilengkapi dengan LKPD, lembar evaluasi, lembar aktivitas peserta didik, kunci jawaban, pedoman penilain, lembar refleksi, dan video pembelajaran yang dibuat sendiri oleh peneliti. Hal tersebut telah sesuai dengan kriteria buku panduan berkualitas menurut (Pusat Perbukuan, 2018) mengenai bagian isi buku yaitu memberikan panduan tentang metode, media, dan penilaian pembelajaran guna meningkatkan kapasitas pedagogik, sosial, dan profesionalitas pendidik. 
1239 Pengembangan Buku Panduan Guru Materi Debit Berbasis Etnomatematika Menggunakan Tradisi Bercocok Tanam Padi di Kulon Progo - Syifa Aliffia, Christiyanti Aprinastuti, Maria Agustina Amelia DOI: https://doi.org/10.31004/edukatif.v4i1.2147

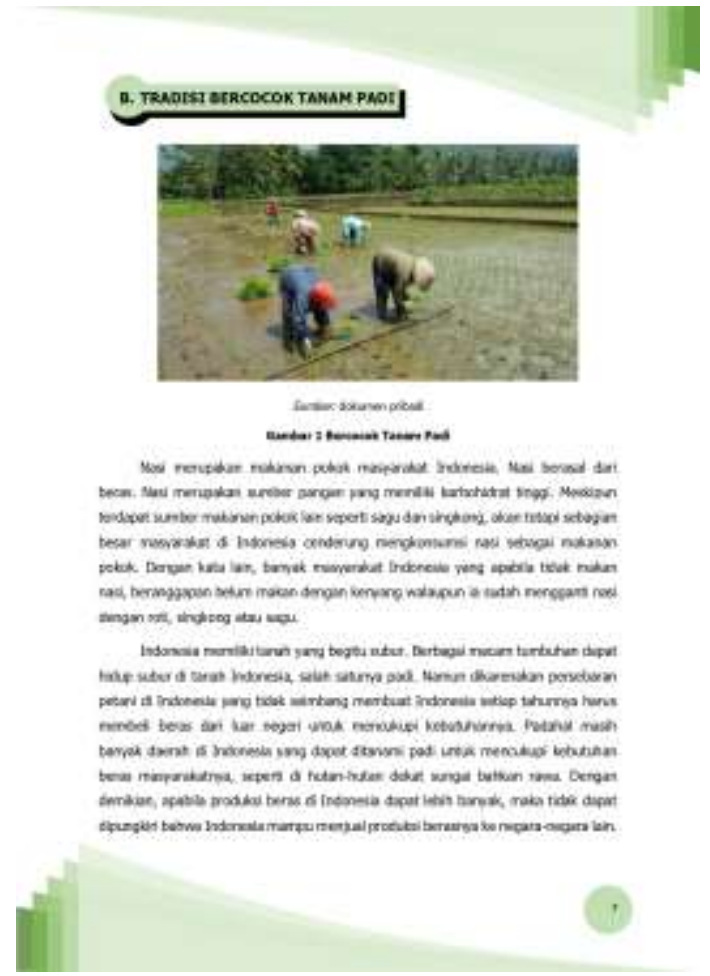

Gambar 2. Lembar Teori

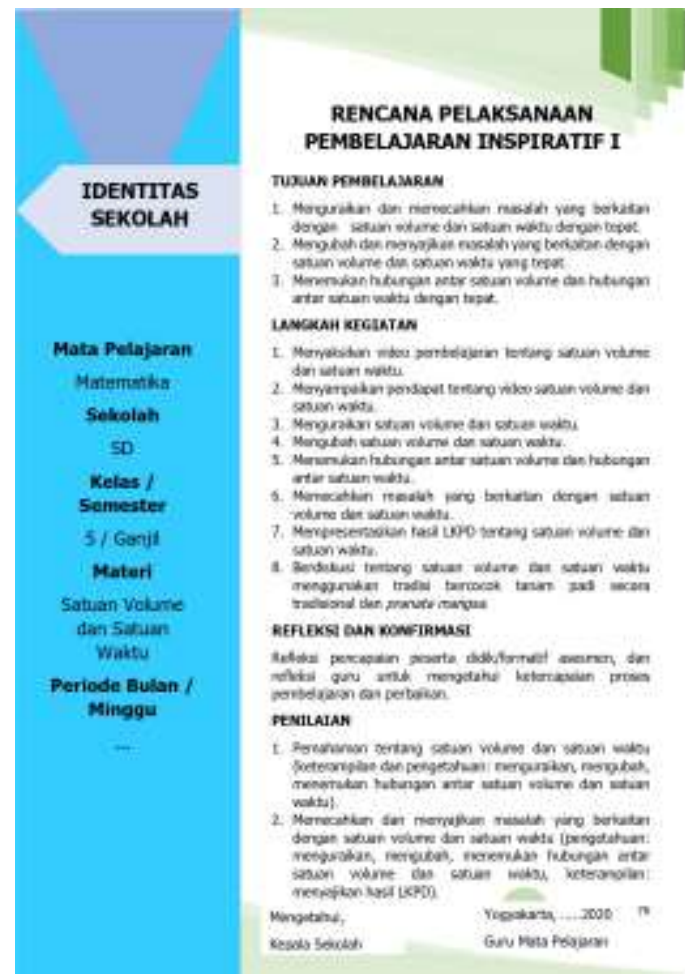

Gambar 4. Rencana Pelaksanaan Pembelajaran 1 lembar

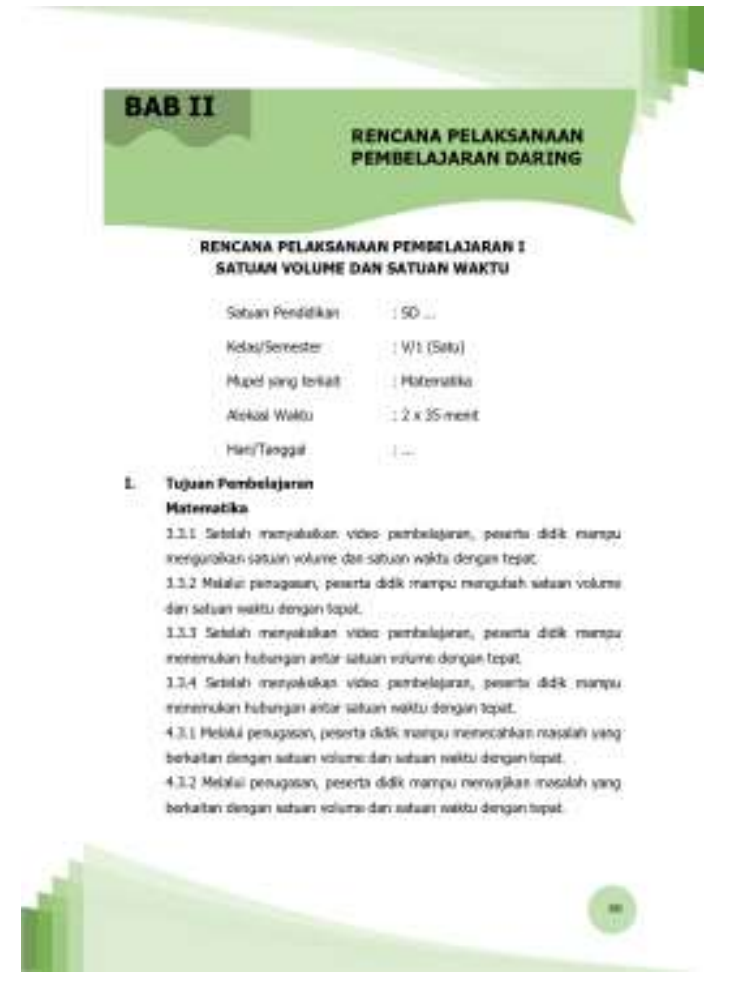

\section{Gambar 3. Rencana Pelaksanaan} Pembelajaran Lengkap

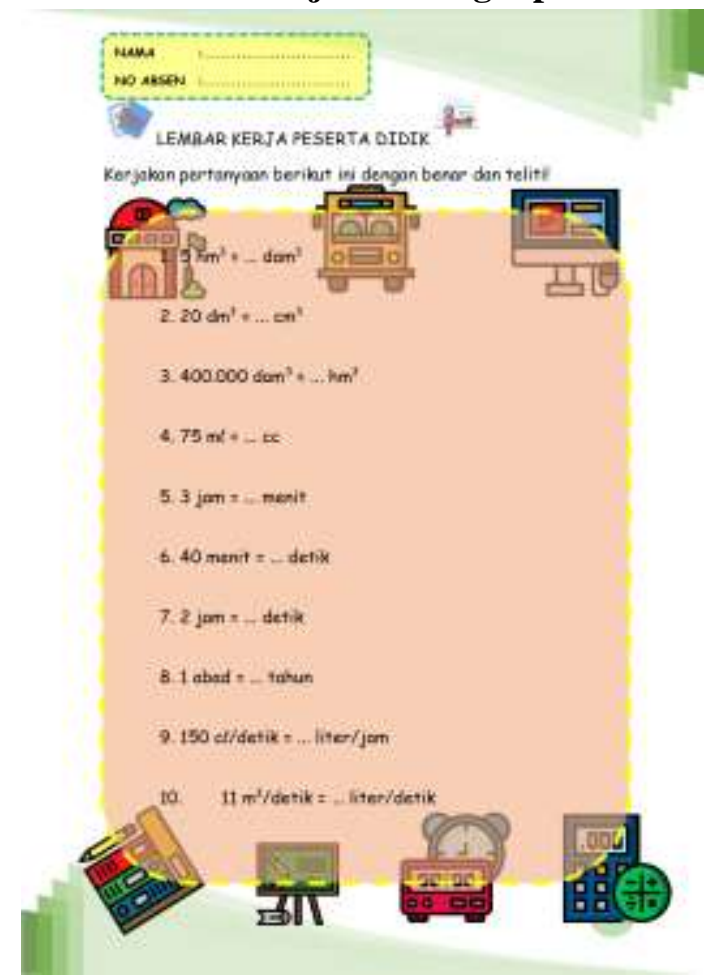

Gambar 5. LKPD 
1240 Pengembangan Buku Panduan Guru Materi Debit Berbasis Etnomatematika Menggunakan Tradisi Bercocok Tanam Padi di Kulon Progo - Syifa Aliffia, Christiyanti Aprinastuti, Maria Agustina Amelia DOI: https://doi.org/10.31004/edukatif.v4i1.2147

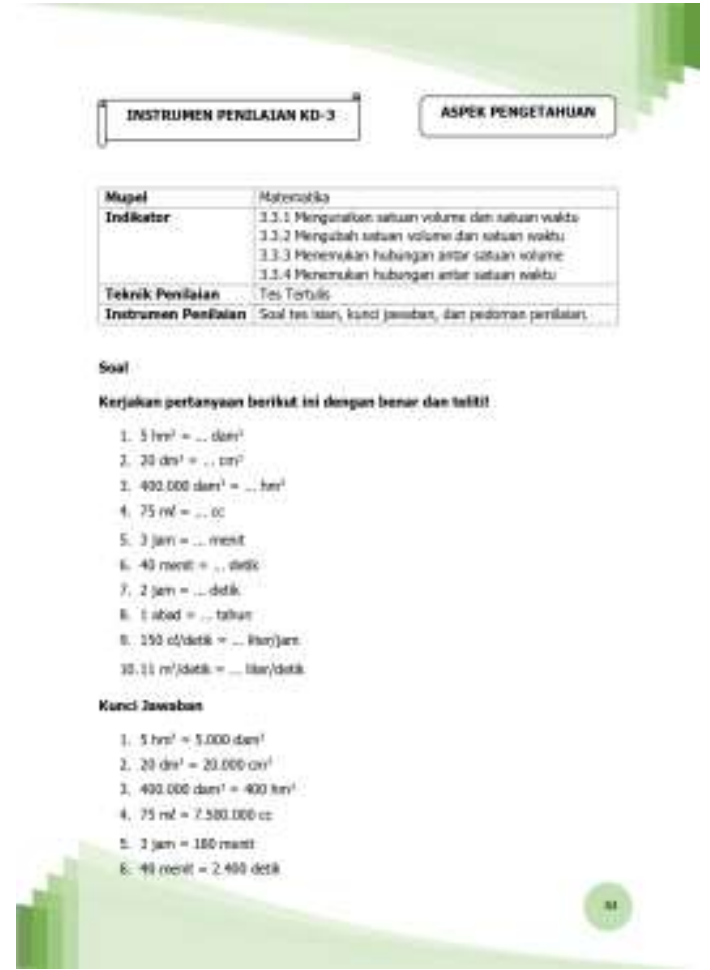

Gambar 6. Pedoman Penilaian

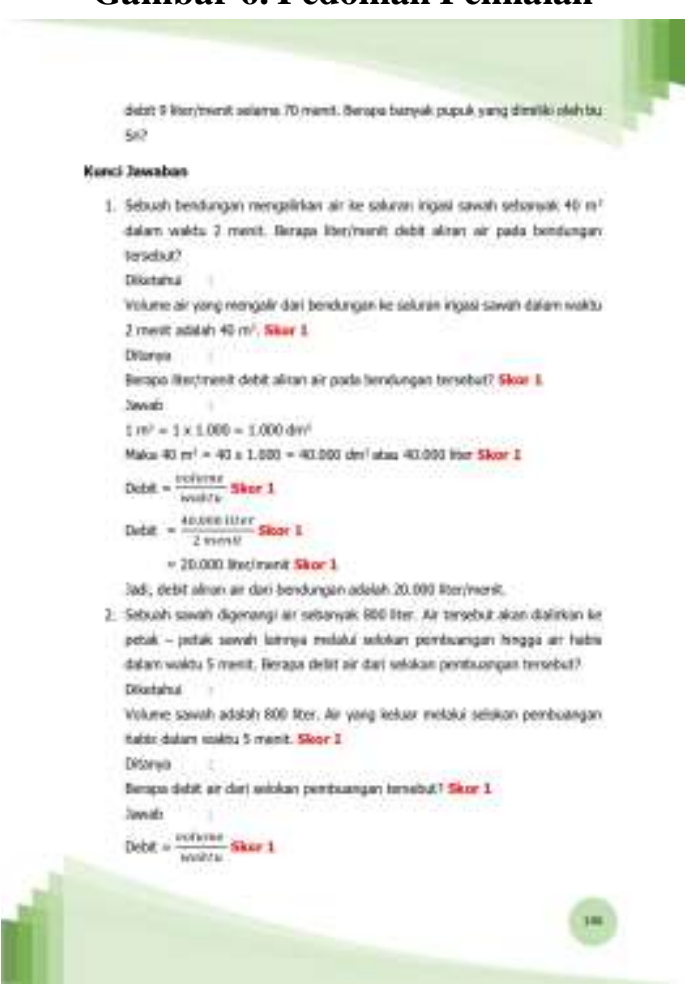

Gambar 8. Kunci Jawaban

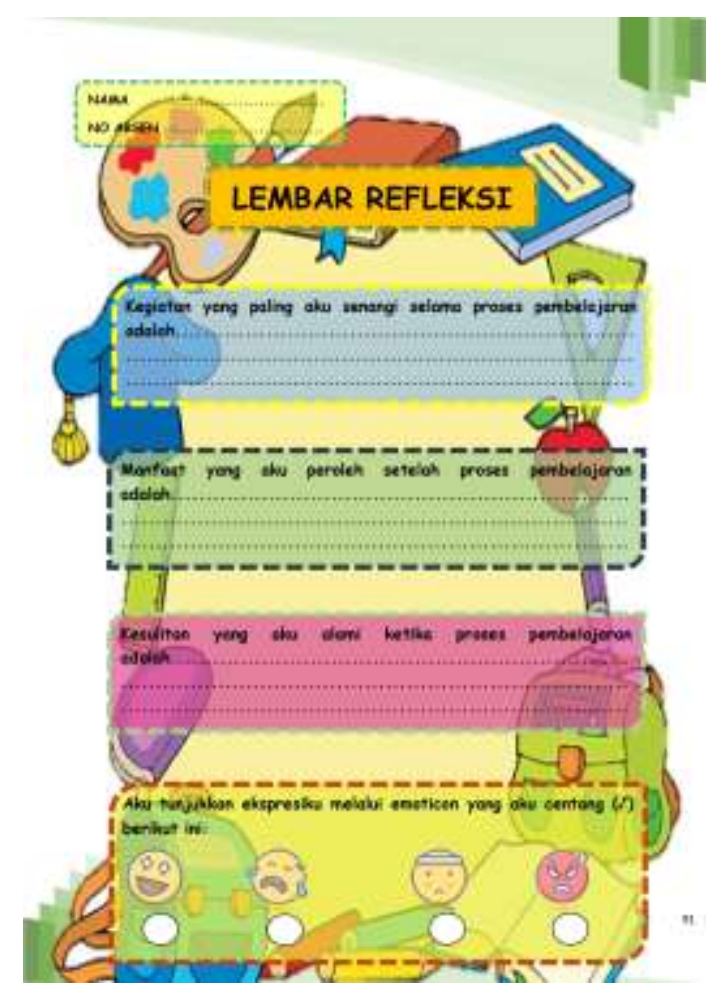

Gambar 7. Lembar Refleksi

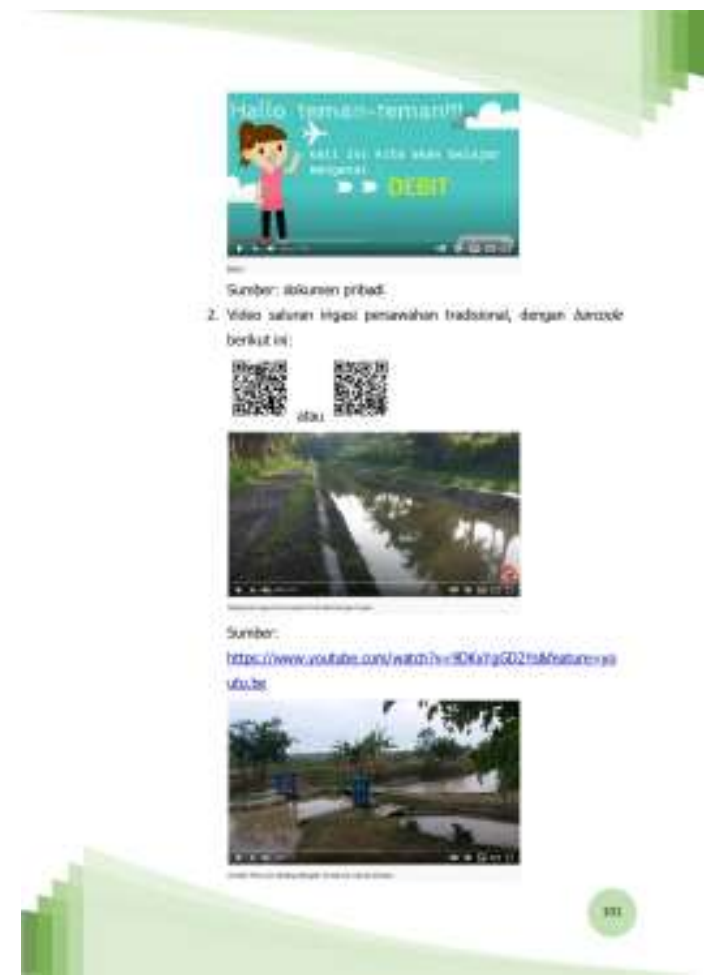

Gambar 9. Video Pembelajaran

6. Pada buku panduan guru peneliti menambahkan daftar pustaka untuk menuliskan sumber-sumber referensi yang digunakan dalam menyusun buku panduan guru. Dengan demikian, isi buku panduan guru mampu dipertanggungjawabkan karena mencantumkan sumber referensi yang digunakan dalam penyusunan buku panduan, sehingga buku panduan guru telah sesuai dengan kriteria buku panduan berkualitas menurut (Pusat Perbukuan, 2018) mengenai bagian isi buku yaitu memiliki muatan isi yang 
1241 Pengembangan Buku Panduan Guru Materi Debit Berbasis Etnomatematika Menggunakan Tradisi Bercocok Tanam Padi di Kulon Progo - Syifa Aliffia, Christiyanti Aprinastuti, Maria Agustina Amelia DOI: https://doi.org/10.31004/edukatif.v4i1.2147

dapat dipertanggungjawabkan, dengan mencantumkan sumber rujukan pada daftar referensi di halaman akhir buku.

7. Dalam buku panduan guru, bahasa yang digunakan telah sesuai dengan Kamus Besar Bahasa Indonesia (KBBI) dan struktur kalimat juga disusun menggunakan gaya bahasa yang semiformal atau SPOK. Hal tersebut sesuai dengan pernyataan dari (Utama \& Widyani, 2014) yang menjelaskan bahwa salah satu ciri-ciri buku panduan yang baik adalah struktur kalimat yang digunakan minimal harus SPOK dan menggunakan gaya bahasa yang semiformal. Sehingga buku panduan guru telah sesuai dengan kriteria buku panduan berkualitas menurut (Pusat Perbukuan, 2018) mengenai bagian isi buku yaitu memiliki tata bahasa dan gaya penyajian yang baik agar mudah dipahami, buku-buku hasil alih bahasa dari bahasa asing ke bahasa Indonesia harus memiliki kualitas terjemahan yang baik.

8. Pada bagian akhir buku ini, peneliti mencantumkan daftar pustaka. Daftar pustaka dicantumkan untuk menuliskan sumber referensi yang digunakan oleh peneliti dalam menyusun buku panduan guru etnomatematika tradisi bercocok tanam padi di Kulon Progo materi debit untuk kelas 5 SD. Hal tersebut telah sesuai dengan kriteria buku panduan berkualitas menurut (Pusat Perbukuan, 2018) mengenai bagian akhir buku yaitu daftar pustaka, daftar istilah dalam bentuk glosarium, indeks, dan lampiran.

Dalam buku panduan guru etnomatematika tradisi bercocok tanam padi di Kulon Progo materi debit untuk kelas 5 SD berisi Rencana Pelaksanaan Pembelajaran (RPP) daring yang telah memenuhi kriteria penyusunan perencanaan pembelajaran menurut Sanjaya (Ananda, 2019), yaitu:

1. Langkah-langkah pembelajaran dalam RPP telah dibuat efektif dan efisien, sehingga proses pembelajaran akan berjalan dengan bermakna. Setiap langkah pembelajaran memiliki makna untuk setiap peserta didik, oleh sebab itu apabila satu langkah pembelajaran tidak dilaksanakan atau dihilangkan, maka proses pembelajaran akan kehilangan salah satu maknanya. RPP disusun sebagai bagian dari proses pembelajaran matematika materi debit berbasis etnomatematika menggunakan tradisi bercocok tanam padi di Kulon Progo sesuai dengan kebutuhan peserta didik. Hal tersebut telah sesuai dengan kriteria penyusunan perencanaan pembelajaran menurut Sanjaya (Ananda, 2019) yaitu signifikansi.

2. RPP yang telah disusun dalam buku panduan guru sesuai dengan kurikulum yang berlaku yaitu Kurikulum 2013 serta sesuai dengan kebutuhan peserta didik. Dengan demikian, Rencana Pelaksanaan Pembelajaran (RPP) telah sesuai dengan kriteria penyusunan perencanaan pembelajaran menurut Sanjaya (Ananda, 2019) yaitu relevan.

3. Pembaca atau pengguna buku panduan tidak lagi harus memilih alternatif-alternatif lain dalam mengimplementasikan RPP yang terdapat dalam buku panduan guru dikarenakan RPP memiliki langkah-langkah pembelajaran yang pasti, tetapi pembaca atau pengguna buku panduan dapat mengembangkan RPP sesuai dengan kebutuhan dan tujuan yang hendak dicapainya. Hal tersebut telah sesuai dengan kriteria penyusunan perencanaan pembelajaran menurut Sanjaya (Ananda, 2019) yaitu kepastian.

4. Pembaca atau pengguna buku panduan dapat menggunakan RPP dalam berbagai kondisi. RPP yang termuat dalam buku panduan guru bersifat lentur, sehingga pembaca atau pengguna buku mampu mengimplementasikan RPP secara bebas tanpa perlu memperhatikan syarat-syarat yang harus dipenuhi. RPP dalam buku panduan guru yang bersifat lentur sesuai dengan kriteria penyusunan perencanaan pembelajaran menurut Sanjaya (Ananda, 2019) yaitu adaptabilitas.

5. Rencana Pelaksanaan Pembelajaran (RPP) disusun dengan menekankan sifat sederhana. Tertera dalam bahasa yang digunakan, langkah-langkah pembelajaran, media pembelajaran, LKPD, lembar aktivitas peserta didik, lembar evaluasi, kunci jawaban, dan pedoman penilaian, maka pembaca atau pengguna buku panduan akan mudah untuk menerjemahkan dan mengimplementasikan RPP yang termuat dalam 
1242 Pengembangan Buku Panduan Guru Materi Debit Berbasis Etnomatematika Menggunakan Tradisi Bercocok Tanam Padi di Kulon Progo - Syifa Aliffia, Christiyanti Aprinastuti, Maria Agustina Amelia DOI: https://doi.org/10.31004/edukatif.v4i1.2147

buku panduan guru. Hal tersebut telah sesuai dengan kriteria penyusunan perencanaan pembelajaran menurut Sanjaya (Ananda, 2019) yaitu kesederhanaan.

6. Wabah penyakit Covid-19 seperti yang tengah melanda Indonesia membuat kegiatan belajar mengajar dilaksanakan secara jarak jauh. Hal tersebut tidak pernah terbayangkan oleh para guru di Indonesia bahwasanya kegiatan belajar mengajar akan dilaksanakan secara jarak jauh. Oleh sebab itu, RPP yang telah disusun memperhatikan daya ramal yang akan terjadi, sehingga pembaca atau pengguna buku panduan dapat mengantisipasi apa yang akan terjadi dalam kegiatan belajar mengajar. RPP yang telah disusun dapat digunakan untuk proses pembelajaran jarak jauh dan proses pembelajaran tatap muka. Hal ini menunjukkan bahwa RPP yang telah disusun sesuai dengan kriteria penyusunan perencanaan pembelajaran menurut Sanjaya (Ananda, 2019) yaitu prediktif.

Berdasarkan uraian di atas, diperoleh hasil bahwa dalam tradisi bercocok tanam padi memuat unsurunsur matematika meliputi satuan panjang, satuan luas, satuan waktu, satuan volume, dan debit. Hal tersebut sesuai dengan hasil penelitian yang dilaksanakan oleh (Suprayo et al., 2018) bahwa banyak aktivitas etnomatematika dalam kegiatan bertani yang dilakukan oleh masyarakat Desa Suranenggala Kidul dan Gegesik Cirebon, meliputi membilang yaitu sebentel, rong bentel, telung bentel, dan gegula; aktivitas mengukur yaitu hasta, depa, belek, sebatok wolu, seter, sekocel, sedangan serta legowo loro dana legowo papat; aktivitas menghitung yaitu pada jumlah pupuk yang digunakan ketika metode yang digunakan berbeda seperti rong kintal dan telung kintal.

Buku panduan guru etnomatematika tradisi bercocok tanam padi di Kulon Progo materi debit untuk kelas 5 SD memiliki beberapa kelebihan. Kelebihan dari buku panduan ini terdapat pada isi buku, bagian dalam buku panduan ini terdiri dari teori-teori etnomatematika, tradisi bercocok tanam padi, debit, dan model pembelajaran Problem Based Learning yang mendukung, serta Rencana Pelaksanaan Pembelajaran (RPP) yang terdiri dari tiga RPP yang membahas mengenai materi satuan volume dan satuan waktu, materi debit, dan materi debit dalam kehidupan sehari-hari. Selain itu, RPP juga dibuat dengan tujuan dan indikator yang dikembangkan oleh peneliti yang dilengkapi dengan media pembelajaran berupa video pembelajaran yang sebagian dibuat sendiri oleh peneliti, Lembar Kerja Peserta Didik (LKPD), lembar aktivitas peserta didik, lembar evaluasi, kunci jawaban, pedoman penilaian, dan lembar refleksi. Selain itu, buku panduan tersebut juga dapat memberikan pemahaman baru kepada pembaca atau pengguna buku panduan bahwa dalam tradisi bercocok tanam padi terdapat unsur matematika yang dapat digunakan dalam mengatasi permasalahan peserta didik dalam pembelajaran matematika terkhusus materi debit. Namun, buku panduan guru yang telah peneliti kembangkan ini juga memiliki ketebatasan yaitu buku panduan guru hanya mencakup materi pembelajaran debit untuk kelas V SD. Buku panduan guru ini dikembangkan dengan tujuan dalam bidang pendidikan mampu digunakan untuk menanamkan sikap melestarikan dan mengenalkan kembali budaya-budaya atau tradisi yang dimiliki bangsa Indonesia, menanamkan nilai karakter budaya bangsa kepada generasi milenial, dan memberikan pemahaman serta referensi baru kepada pengguna buku bahwa melalui tradisi bercocok tanam padi dapat diintegrasikan dalam pembelajaran matematika materi debit untuk kelas V SD. Hal tersebut sesuai dengan pendapat (Suwarsono, 2015) bahwa salah satu tujuan dari kajian tentang etnomatematika yaitu agar keterkaitan antara matematika dan budaya bisa lebih dipahami, sehingga persepsi siswa dan masyarakat tentang matematika menjadi lebih tepat dan pembelajaran matematika bisa lebih disesuaikan dengan konteks budaya siswa dan masyarakat, serta matematika bisa lebih mudah dipahami karena tidak lagi dipersepsikan sebagai sesuatu yang "asing" oleh siswa dan masyarakat.

\section{KESIMPULAN}

Pengembangan buku panduan guru etnomatematika tradisi bercocok tanam padi di Kulon Progo materi debit untuk kelas 5 SD menggunakan model penelitian ADDIE, yaitu: (1) analyze (analisis); (2) design 
1243 Pengembangan Buku Panduan Guru Materi Debit Berbasis Etnomatematika Menggunakan Tradisi Bercocok Tanam Padi di Kulon Progo - Syifa Aliffia, Christiyanti Aprinastuti, Maria Agustina Amelia DOI: https://doi.org/10.31004/edukatif.v4i1.2147

(perancangan); (3) development (pengembangan); (4) implementation (implementasi); dan (5) evaluation (evaluasi).

Kualitas buku panduan guru etnomatematika tradisi bercocok tanam padi di Kulon Progo materi debit untuk kelas 5 SD, memiliki kualitas "Sangat Baik" dengan rerata skor validasi sebesar 3,55 dari skala empat. Buku panduan guru tersebut telah memenuhi kriteria buku panduan yang berkualitas menurut (Pusat Perbukuan, 2018) serta Rencana Pelaksanaan Pembelajaran (RPP) Daring yang terdapat dalam buku panduan telah memenuhi kriteria penyusunan perencanaan pembelajaran menurut Sanjaya (Ananda, 2019).

\section{DAFTAR PUSTAKA}

Afifah, N. (2017). Implementasi Pembelajaran Berbasis Multikultur dan Budaya di SD/MI. AR-RIAYAH: Jurnal Pendidikan Dasar, 1(1), 23. https://doi.org/10.29240/jpd.v1i1.217

Ananda, R. (2019). Dr. Rusydi Ananda, M.Pd.

Irsyad, M., Sujadi, A. A., \& Setiana, D. S. (2020). Eksplorasi Etnomatematika pada Candi Asu. UNION: Jurnal Ilmiah Pendidikan Matematika, 8(1), 11. https://doi.org/10.30738/union.v8i1.7609

Jamaris, M. (2014). Kesulitan Belajar: Perspektif, Asesmen, dan Penanggulangannya Bagi Anak Usia Dini dan Usia Sekolah (1st ed.). Ghalia Indonesia.

Mardapi, D. (2008). Teknik Penyusunan Instrumen Tes dan Nontes. Mitra Cendekia Press.

Model, P., Etnomatematika, P., Untuk, S., Berpikir, K., Siswa, K., \& Dasar, S. (2015). Nurul Haque,2015 Pengaruh Model Pembelajaran Etnomatematika Sunda untuk Meningkatkan Kemampuan Berpikir Kritis Siswa Sekolah Dasar Universitas Pendidikan Indonesia|repository.upi.edu|perpustakaan.upi.edu. 2014-2015.

Oktavianti, I., Zuliana, E., \& Ratnasari, Y. (2017). Menggagas Kajian Kearifan Budaya Lokal di Sekolah Dasar Melalui Gerakan Literasi Sekolah. Prosiding Seminar Nasional, 1(1), 35-42. https://unikom.journal.ac.id/

Pusat Perbukuan. (2018). Panduan Pemilihan Buku Nonteks Pelajaran.

Ramadan, Z. H. (2018). Pemahaman Kearifan Lokal Di Sekolah Dasar Sebagai Suatu Cara Membentuk Karakter Siswa. 84-93. https://ejournal.unri.ac.id/index.php/pigur/article/view/5415

Sarwoedi, Marinka, D. O., Febriani, P., \& Wirne, I. N. (2018). Efektifitas Etnomatematika dalam Meningkatkan Kemampuan Pemahaman Matematika Siswa. Jurnal Pendidikan Matematika Raflesia, 03(02), 171-176. https://ejournal.unib.ac.id/index.php/jpmr/article/view/7521

Sitepu, B. . (2012). Penulisan Buku Teks Pelajaran. PT Remaja Rosdakarya.

Suherman, H.H, D. (2001). Strategi Pembelajaran Matematika Kontemporer. JICA-Universitas Pendidikan Indonesia (UPI).

Suprayo, T., Nuryusri, \& Noto, M. S. (2018). Studi Etnomatematika Masyarakat Petani Kabupaten Cirebon. Prosiding SNMPM, 2(1), 49-54.

Susanto, A. (2013). Teori Belajar dan Pembelajaran di Sekolah Dasar. Kencana.

Suwarsono, S. (2015). Etnomatematika (Ethnomatematics). Materi Kuliah S2 Pendidikan Matematika Universitas Sanata Dharma.

Tegeh, I.M, Jampel, I.N, Pudjawan, K. (2014). Model Penelitian Pengembangan. Graha Ilmu.

Utama, A. N. B., \& Widyani, R. (Ed. ). (2014). Cara Praktis Menulis Buku. 